\title{
FUZZY LOGIKA ALAPÚ KOCKÁZAT ÉRTÉKELŐ KERETRENDSZER ALKALMAZÁSA A PÁCIENSMONITOROZÁSBAN
}

\section{FUZZY LOGIC-BASED RISK ASSESSMENT FRAMEWORK USED IN PATIENT MONITORING}

Tóthné Laufer Edit

\author{
Óbudai Egyetem, Bánki Donát Gépész és Biztonságtechnikai Mérnöki Kar, \\ Mechatronikai és Jármütechnikai Intézet, 1081, Magyarország, Budapest, \\ Népszínház u. 8. Telefon / Fax: +361666-5377, laufer.edit@bgk.uni-obuda.hu
}

\begin{abstract}
In this paper a fuzzy logic-based risk assessment framework is introduced, which can be customized based on personal parameters during patient monitoring. In these kinds of systems reliable result can be obtained only in the case of patient-specific evaluation, which takes into account the personal characteristics, living conditions, medical recommendations, case history and the previous measurements available. These requirements and the risk factors diversity justify the development of a flexible and a high degree of adaptability risk assessment system, which has a generalized, modularized structure in order to easy expandability and transparency. The basis of this structure are the specifically configurable subsystems. The uncertainty and the subjectivity in the factors determining and in the evaluation are handled by applying fuzzy logic-based inference system.
\end{abstract}

Keywords: Fuzzy inference system, patient monitoring, risk assessment

\section{Összefoglalás}

Ebben a cikkben egy olyan fuzzy logikán alapuló kockázatértékelő keretrendszert mutatok be, amely személyre szabhatóan, az egyéni adottságoknak megfelelően alkalmazható a páciensmonitorozás során. Ilyen típusú rendszerekben megbízható eredmény csak páciens-specifikus kiértékelés esetén határozható meg, ami figyelembe veszi az egyéni adottságokat, életkörülményeket, orvosi ajánlásokat, az illető kórtörténetét és az esetlegesen rendelkezésre álló előző mérési eredményeket. Ezek az igények, valamint a kockázati tényezők változatossága egy flexibilis, nagyfokú adaptációs képességgel rendelkező kockázatkezelő rendszer kidolgozását tették szükségessé, amely a könnyű bővíthetőség, és átláthatóság elérése érdekében általánosított, moduláris felépítésű rendszerstruktúrával rendelkezik, melynek alapját a specifikusan paraméterezhető alrendszerek képezik. Az ilyen típusú rendszereknél gyakran tapasztalható bizonytalanságot, a tényezők meghatározásában és a kiértékelésben rejlő szubjektivitást fuzzy alapú következtetési rendszer alkalmazásával kezeltem.

Kulcsszavak: Fuzzy következtetési rendszer, páciens monitorozás, kockázatbecslés

\section{Bevezetés}

A rendszeres testmozgás kedvező élettani hatásai, fontos szerepe a prevencióban, rehabilitációban mindenki számára ismertek: mérsékli a testsúlyt és a vérnyomást, szabályozza a szívritmust, javítja az anyagcsere-folyamatokat, csökkenti a szív- és érrendszeri betegségek, az agyi érkatasztrófa (stroke), a 
cukorbetegség, a csontritkulás és az ízületi elváltozások kockázatát. Lelki problémák esetén is kedvezően hat, oldja a szorongást, enyhíti a depressziót, ami szintén kedvező hatást gyakorol a szervezetre. Ismert tény az is, hogy a testmozgás hiánya hosszú távon egészségromlást eredményez, ezáltal rontja az életminőséget. Fontos azonban azt is megjegyezni, hogy a nem megfelelő (káros, vagy túlzásba vitt) sporttevékenység veszélyes is lehet. Ilyen problémát okozhat, ha nem az adottságainknak, aktuális fizikai állapotunknak megfelelő mozgásformát, intenzitást, gyakoriságot, vagy időtartamot választunk. Annak érdekében, hogy a tevékenység biztonságosan végezhető legyen, valós időben kell figyelemmel kísérni a személy alapvető fiziológiai jellemzőit. Ilyen típusú rendszereknél komoly problémát jelenthet a tényezők normál tartományának meghatározása. Az orvostudomány ugyan alkalmaz általánosan elfogadott értéktartományokat [1], de igazán megbízható kiértékelés csak személyre szabott tartományok esetén végezhető [2], figyelembe véve a páciens krónikus betegségeit, aktuális állapotát, életkorát és számos egyéb tényezőt. Ezen problémák kezelésére hoztam létre egy olyan kockázatértékelő keretrendszert, melyben személyre szabhatók a vizsgálandó tényezők, valamint az értékhatárok, a választott sporttevékenységet is figyelembe véve. Mivel élettani jellemzőknél nem éles határokkal dolgozunk, fuzzy alapú kiértékelést alkalmaztam.

\section{A rendszer felépítése}

\subsection{A keretrendszer}

A könnyü bővíthetőség érdekében a rendszer csoportosított, hierarchikus felépítésü, melyben a kiértékelés fuzzy logikán alapul. A cél személyre szabott paraméterek alapján a kockázati szint meghatározása, a kritikus helyzetek felismerése érdekében. A rendszer bemeneti paraméterei és azok értékhatárai nem általánosan meghatározottak, hanem a személyes adatokat tartalmazó adatbázis alapján állnak elő, ennek megfelelően az alkalmazott szabályrendszer is személyre szabott, hiszen annak antecedens része a bemenetek függvénye [3]. A rendszerstruktúra alapját a jellegüknél fogva összetartozó tényezők képezték, melyek önálló alrendszereket alkotnak, kezelésük is külön történik. A modell általános felépítése az 1. ábrán látható.

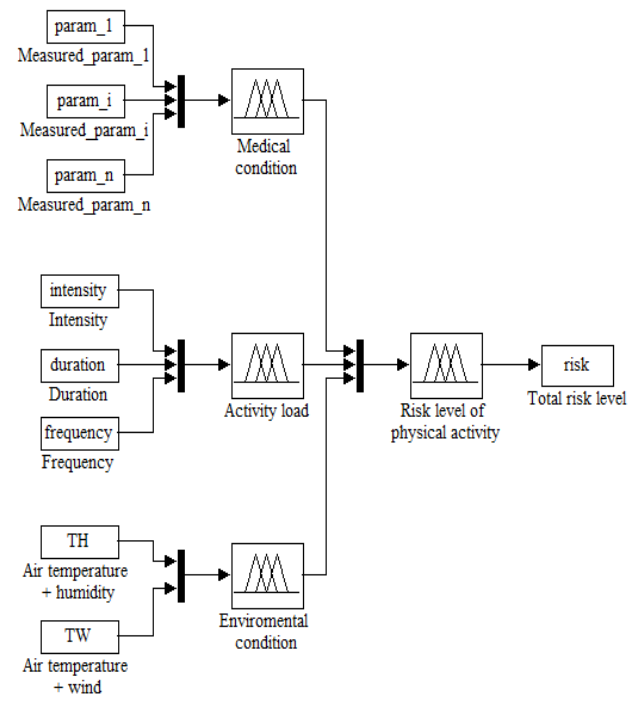

1. ábra. A rendszer általános felépitése

A rendszer személyre szabhatóságát a „Medical condition” alrendszer képezi, ennek bemenetei a választott mozgásforma és a személyes jellemzők alapján az adatbázisban egyénileg definiáltak, ezek monitorozása valós időben történik.

Az „Activity load” alrendszer a személy sporttevékenységével kapcsolatos szokásait tartalmazza, mint a mozgás gyakorisága (Frequency), időtartama (Duration) és intenzitása (Intensity).

$\mathrm{Az}$ „Environmental condition” alrendszer pedig a környezeti tényezőket vizsgálja, a hőmérsékletnek a széllel (TW), 
illetve a páratartalommal $(\mathrm{TH})$ kombinált hatását veszi figyelembe.

A rendszer felépítésének köszönhetően az egyes alrendszerek külön bővíthetők, módosíthatók a személy állapotában bekövetkezett változáshoz alkalmazkodva, az adatbázis alapján, hiszen a határértékeket ott definiáljuk.

\subsection{A kiértékelés folyamata és az alkalmazott adatbázis}

A rendszer megfelelő müködéséhez egy jól megtervezett adatbázisra volt szükség, amely tartalmazza a vizsgálandó tényezőket és a tagsági függvény hangolásához szükséges paramétereket a személyes jellemzőktől és a sporttevékenységtől függően. Az antecedens halmazok száma és neve felhasználótól függetlenül adott, de a kiértékeléskor azok hangolása az adatbázisban megadott értékek alapján történik, akárcsak a kiértékelő szabályok meghatározása, de ez már személyre szabottan történik.

\subsubsection{Az adatbázis inicializálása}

A rendszer első használata előtt az adatbázis alapértékeit be kell állítani, illetve, ha a páciens állapotában bármiféle változás történik, a szükséges értékeket, módosítani kell. Az egyed-kapcsolat diagram alapján alkalmazott relációk a következők:

Felhasználók(TAJ, Név, Cím, Születési dátum, Nem, Magasság, Testsúly): A felhasználó alapvető adatait tartalmazza, kulcs attribútuma a TAJ szám, ami a felhasználó társadalombiztosítási azonosító jele.

Sportok(TAJ, sport): A felhasználó által végzett lehetséges mozgásformákat tartalmazza, melynek során monitorozni kell öt. Kulcs attribútum a TAJ szám.

Antecedensek száma(param, MFszám): $\mathrm{Az}$ értelmezési tartományon belül definiált határértékek adják meg a kiértékelés során, az egyes tényezők esetén alkalmazott antecedens halmazokat, melyek száma a paraméter jellemzőjétől függ. A tartomány felosztható például normál, emelkedett, és abnormális értékekre, ekkor három halmaz szükséges, de ez az egyes tényezők esetén különböző lehet. A halmazok száma nem páciens, hanem paraméterfüggő, ezért a reláció kulcs attribútuma a param.

Antecedens név(param, MFnév): szorosan kapcsolódik az előző relációhoz, mivel az abban meghatározott halmazok neveit tartalmazza, így ezek száma értelem szerüen megegyezik a halmazok számával. Ezek az elnevezések nem felhasználó, hanem paraméterfüggőek, ezért a reláció kulcs attribútuma a param.

\subsubsection{A kiértékelés lépései}

Ebben az alfejezetben a kiértékelés lépéseit egy alrendszerre mutatom be diszkretizált kimenetű Mamdani-típusú rendszer esetén. A rendszer moduláris felépítésének következtében a többi alrendszerben ugyanezek a lépések hajthatók végre.

1. lépés: A mérendő tényezők és azok száma felhasználótól és a választott mozgásformától függően különbözőek lehetnek, melyek a személyes profilban a Vizsgált_param(TAJ, sport, param) relációban vannak definiálva. Kulcs attribútumok a TAJ szám és a választott sport együtt. Az így definiált értékeket fuzzifikálni kell, melyre a rendszerben (1) által definiált trapéz alakú függvényt használtam.

$$
\mu_{A}(x)=\left\{\begin{array}{cc}
0 & x \leq a_{i} \\
\frac{x-a_{i}}{b_{i}-a_{i}} & a_{i} \leq x \leq b_{i} \\
1 & b_{i} \leq x \leq c_{i} \\
\frac{d_{i}-x}{d_{i}-c_{i}} & c_{i} \leq x \leq d_{i} \\
0 & d_{i} \leq x
\end{array}\right.
$$

ahol $\mathrm{a}_{\mathrm{i}}, \mathrm{b}_{\mathrm{i}}, \mathrm{c}_{\mathrm{i}}, \mathrm{d}_{\mathrm{i}}$, a függvény paraméterek, melyek a függvény felhasználó-specifikus 
hangolására használhatók az adatbázisban megadott értékek alapján, melyek a Paraméter_határértékek(TAJ, MFnév, határértékek, sport) relációban találhatók, a Vizsgált_param relációban szerepelő tényezőkre kell alkalmazni. A kapott értékek definiálják a tartományok legkisebb és legnagyobb értékét, illetve a függvény paramétereket minden egyes antecedens halmaz esetén, a felhasználótól és a választott sporttevékenységtől függően. Kulcs attribútuma a TAJ szám, az MFnév és a sport együtt.

2. lépés: A szabálypremisszák $\left(w_{i}\right)(2)$ alapján definiálhatók, ahol a fuzzifikált értékeket az AHP módszer szerint súlyoztam, ennek értékei a Kölcsönhatások (TAJ,sport,index,érték) relációban adottak. Ez a reláció adja meg a paraméterek relatív fontosságát felhasználó- és sport-specifikus módon. Az alapértelmezett összehasonlító mátrix megadható minden egyes paraméterkombinációra, de felhasználótól függően módosíthatók az értékei.

$$
w_{1}=\left\{\begin{array}{cc}
m \cdot \sum_{k=1}^{m} a_{k} \mu_{A_{k j}}\left(x_{k}\right) & \text { ha } \\
0 & \text { különben }
\end{array} \mu_{A_{k j}} \neq 0, \forall k \in[1, m]\right.
$$

ahol $\mathrm{m}$ az bemenő paraméterek száma, $\mathrm{a}_{\mathrm{k}} \mathrm{a}$ k. bemenethez tartozó súly, $\mathrm{w}_{\mathrm{i}}$ az $\mathrm{i}$. szabálypremissza tüzelési szintje.

3. lépés: A szabályok konzekvens részének defuzzifikációja a COG módszer (3) alapján, ahol ismét trapéz alakú tagsági függvényeket alkalmazunk. A

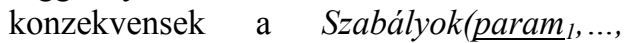
param $_{n}$,kimenet) relációban vannak definiálva felhasználó- és sport-specifikus módon. A reláció kulcs attribútuma a paraméter kombináció, amely a 2 . lépésben alkalmazott szabálypremisszákat definiálja.

$$
f_{i}=\frac{\int_{\operatorname{supp}_{D_{i}}} \mu_{D_{i}}(y) y d y}{\int_{\operatorname{supp}_{D_{i}}} \mu_{D_{i}}(y) d y}
$$

4. lépés: $A z$ összesített kimenet $(\mathrm{O})$ kiszámítása (4) alapján.

$$
O=\sum_{i=1}^{n} \bar{w}_{i} f_{i}=\frac{\sum_{i=1}^{n} w_{i} f_{i}}{\sum_{i=1}^{n} w_{i}}
$$

\section{Következtetések}

Páciensmonitorozó rendszerekben a kiértékelés személyre szabhatósága nehezen megvalósítható, de valós eredmény csak így kapható. A probléma kezelése érdekében egy olyan fuzzy alapú kockázatbecslő keretrendszert hoztam létre, ami a személyes profil alapján lehetővé teszi, hogy az adottságoknak megfelelően különböző tényezőket mérjünk, és azok határértékei is személyre szabottan, a választott sportot is figyelembe véve határozhatók meg. A rendszer hierarchikus, csoportosított felépítésủ, így könnyen bővíthetők, módosíthatók az egyes alrendszerek. A felhasználó állapotában bekövetkező változásokhoz pedig az adatbázis értékeinek módosításával tud alkalmazkodni a rendszer.

\section{Szakirodalmi hivatkozások}

[1] Takács, M.; Tóth-Laufer, E: System Model for the Risk Level Calculation of the Leisure Activity. Advances in Accounting, Auditing and Risk Management, Brasov, Romania, 2013, pp. 17-21.

[2] Douglas, $\mathrm{H}$ : The Failure of Risk Management: Why it's Broken and How to Fix it. John Wiley \& Sons, 2009, pp. 46.

[3] Johanyák, Zs. Cs: A Hybrid Algorithm for Parameter Tuning in Fuzzy Model Identification. Acta Polytechnica Hungarica, Vol. 9. No. 6, 2012, pp. 153-165. 